\title{
Treatment with green tea extract attenuates secondary inflammatory response in an experimental model of spinal cord trauma
}

\author{
Irene Paterniti • Tiziana Genovese • Concetta Crisafulli • Emanuela Mazzon • \\ Rosanna Di Paola • Maria Galuppo • Placido Bramanti • Salvatore Cuzzocrea
}

Received: 7 January 2009 / Accepted: 13 March 2009/Published online: 1 April 2009

(C) The Author(s) 2009. This article is published with open access at Springerlink.com

\begin{abstract}
In this study, we evaluated the effect of green tea extract (that was administered $25 \mathrm{mg} / \mathrm{kg}$ intraperitoneal at 1 and $6 \mathrm{~h}$ after injury) in experimental animal model of spinal cord injury. The spinal cord trauma was induced by the application of vascular clips to the dura via a four-level T5T8 laminectomy. Spinal cord injury in mice resulted in severe trauma characterised by oedema, neutrophilic infiltration and apoptosis. Also, immunohistochemical examination demonstrated a marked increase in immune reactivity for nitrotyrosine. All parameters of inflammation were attenuated by green tea extract. The degree of spinal cord inflammation, nitrotyrosine, poli (ADP-ribosio) synthetase (PARS) and neutrophilic infiltration was markedly reduced. Green tea extract significantly ameliorated the recovery of limb function. Values shown are mean $\pm \mathrm{SE}$ mean of ten mice for each group. ${ }^{*} p<0.01$ versus sham, ${ }^{\circ} p<0.01$ versus spinal cord injury. Taken together, our results clearly demonstrate that green tea extract treatment ameliorates spinal cord injury oxidative stress.
\end{abstract}

Keywords Green tea extract - Spinal cord injury · Neutrophilic infiltration · iNOS · NF-kB · Oxidative stress

Irene Paterniti, Tiziana Genovese and Salvatore Cuzzocrea contributed equally to this work.

I. Paterniti $\cdot$ T. Genovese $\cdot$ C. Crisafulli $\cdot$ M. Galuppo •

S. Cuzzocrea

Department of Clinical and Experimental Medicine

and Pharmacology, School of Medicine, University of Messina,

Torre Biologica, Policlinico Universitario Via C. Valeria, Gazzi,

98100 Messina, Italy

E. Mazzon • R. Di Paola $\cdot$ P. Bramanti $\cdot$ S. Cuzzocrea $(\triangle)$

IRCCS Centro Neurolesi "Bonino-Pulejo",

Messina, Italy

e-mail: salvator@unime.it

\section{Introduction}

Spinal cord injury (SCI) is a highly debilitating pathology, could have traumatic or non-traumatic origin and often could lead to devastating and catastrophic dysfunction. SCI imposes high physical and psychological effects not only to the individual but also to the family and society.

The complex pathophysiology of SCI may explain the difficulty for finding a suitable therapy (Stover and Fine 1987). To mimic the majority of mechanical events that lead to various forms of human spinal cord injury, several experimental models have been developed (Beattie et al. 2002); one of the most commonly used model of SCI is the compression model.

In this model, injury is induced by applying either a weight or an aneurysm clip to the spinal cord (Tator and Fehlings 1991) to replicate the persistence of cord compression that is commonly observed in human SCI (Tator 1995).

The pathological events following acute SCI are divided into two chronological phases (Tator and Fehlings 1991). The neurological damage that is incurred following blunt impact and compression to the spinal cord is called "primary injury"; it directly destroys various elements of the tissue and, this causes the death of a number of neurons that cannot be recovered or regenerated. Primary injury to the spinal cord provokes a cascade of cellular and biochemical events that lead to further tissue damage and expansion of the lesion for many days to months after the initial injury. This successive phase is called "secondary injury", and it evokes secondary cell death by three cellular processes: necrosis, completing in minutes to hours; apoptosis, requiring hours to days; and atrophy, proceeding over weeks to months (Tatton et al. 1997) depending on the type and concentration of the death signals. 
It is known that a progressive neuronal injury results from a combination of secondary injury factors including: ischemia, biochemical alterations, excitotoxicity, neurotransmitter accumulation, lipid peroxidation and generation of free radicals (Carlson and Gorden 2002).

It was demonstrated that local and systemic inflammatory response, as well as neurodegenerative disease, are also associated with the production of free radicals like reactive oxygen species (ROS) such as superoxide anions, hydrogen peroxide and peroxynitrite (Cuzzocrea et al. 2001). Oxygen-free radical formation and lipid peroxidation enhance adverse mechanism of neuronal injury, such as spinal cord hypoperfusion, development of oedema, axonal conduction failure and breakdown of energy metabolism.

The importance of free radicals and peroxidation in SCI is supported by the large number of experimental and clinical studies demonstrating potential neuronal efficacy of agents with anti-oxidant proprieties (Genovese et al. 2005b; 2006a, b; La Rosa et al. 2004; Scott et al. 2005).

Green tea extract (GTE) is rich in powerful anti-oxidant compounds called polyphenoles. The polyphones found in tea are more commonly known as flavanols or catechins and comprise $30-40 \%$ of the extractable solids of dried green tea leaves. The main catechines in green tea are epicatechin, epicatechin-3-gallate, epigallocatechin and epigallocatechin-3-gallate (EGCG). EGCG is a major catechin present in green tea. Several epidemiological investigations in various countries reveal beneficial effects of green tea (Hirvonen et al. 2000; Klatsky et al. 1993) as well as black tea (Sato et al. 1989).

Green tea polyphenols have demonstrated significant anti-oxidant, anti-carcinogenic, anti-inflammatory, thermogenic, probiotic and anti-microbial properties in numerous human, animals and in vitro studies (Choi et al. 2004; Crespy and Williamson 2004; Kakuda 2002; Sung et al. 2000). The molecular mechanisms of EGCG appear to include pleiotropic effects. It has been demonstrated that ingestion of green and black tea significantly increased human plasma anti-oxidant capacity in vivo (Serafini et al. 1996). EGCG has been demonstrated to dramatically inhibit chemokine-induced neutrophil chemotaxis in vitro (Dona et al. 2003). Tea polyphones have also been noted to induce apoptosis and cell cycle arrest in a wide array of cell lines (Levites et al. 2002). In addition, the protective effects of tea catechines were evaluated by the attenuation of nitric oxide formation from inducible NO synthase (Chan et al. 1997). This study investigates the effects of a GTE in animal model of spinal cord injury. Additionally, in order to gain a better insight into the mechanisms of action of GTE, we have also investigated the effects of green tea on the following endpoints of the inflammatory process: polymorphonuclear leukocyte (PMN) infiltration measured by myeloperoxidase (MPO) activity, NF-kB activation that plays a central role in the regulation of many genes responsible for the generation of mediators or proteins in inflammation, e.g. tumour necrosis factor- $\alpha$ (TNF- $\alpha$ ), interleukin (IL)-1, inducible NO synthase (iNOS); the activation of the nuclear enzyme poly(ADP-ribose) polymerase (PARP) and apoptosis events.

\section{Materials and methods}

Animals Male adult CD1 mice (25-30 g; Harlan Nossan, Milan, Italy) were housed in a controlled environment and provided with standard rodent chow and water. Animal care was in compliance with Italian regulations on protection of animals used for experimental and other scientific purposes (D.M. 116192) as well as with the European Economic Community regulations (O.J. of E.C. L358/1 12/18/1986).

Green tea extract GTE was a kind gift of Indena (Milano, Italy), and it was defined by the producer as having a polyphenolic content of $75 \pm 5 \%$ with the major constituent being epigallocatechin-3-gallate at $62 \%$ and the minor ones being epicatechin-3-gallate, epigallo catechin and epicathechin.

Spinal cord injury Mice were anaesthetised using chloral hydrate (400 mg/kg body weight). A longitudinal incision was made on the midline of the back, exposing the paravertebral muscles. These muscles were dissected away exposing T5-T8 vertebrae. The spinal cord was exposed via a four-level T6-T7 laminectomy, and SCI was produced by extradural compression of the spinal cord using an aneurysm clip with a closing force of $24 \mathrm{~g}$. In all injured groups, the spinal cord was compressed for $1 \mathrm{~min}$. Sham animals were only subjected to laminectomy. After surgery, $1 \mathrm{ml}$ of saline was administered subcutaneously to replace the blood volume lost during the surgery. During recovery from anaesthesia, the mice were placed on a warm heating pad and covered with a warm towel. Food and water were provided to the mice ad libitum. During this time period, the animal's bladders were manually voided twice a day until the mice were able to regain normal bladder function.

Experimental groups Mice were randomly allocated into the following groups:

1. SCI + vehicle group (N10): mice were subjected to SCI plus intraperitoneal administration of vehicle (saline).

2. $\mathrm{SCI}+$ green tea group (N10): same as the $\mathrm{SCI}+$ vehicle group, plus intraperitoneal administration of green tea extract $(25 \mathrm{mg} / \mathrm{kg})$ at 1 and $6 \mathrm{~h}$ after injury.

3. Sham + vehicle group (N10): mice were subjected to the surgical procedures as the above groups except that the aneurysm clip was not applied. 
4. Sham + green tea group: mice were subject only to laminectomy, and green tea was administered $(25 \mathrm{mg} / \mathrm{kg})$ intraperitoneally at 1 and $6 \mathrm{~h}$ after injury.

As described below, mice ( $N=10$ from each group for each parameter) were killed at $24 \mathrm{~h}$ after SCI in order to evaluate the various parameters. In a separate set of experiments, another ten animals for each group were observed until 10 days after SCI in order to evaluate the motor score. The doses of green tea extract as well as the time of killing were chosen based on previous in vivo studies (Di Paola et al. 2005; Genovese et al. 2008).

Determination of myeloperoxidase activity Myeloperoxidase activity, an indicator of polymorphonuclear leukocyte accumulation, was determined in the spinal cord tissue as previously described at $24 \mathrm{~h}$ after SCI. At the specific time following SCI, spinal cord tissues were obtained and weighed, and each piece of tissue was homogenised in a solution containing $0.5 \%$ hexa-decyl-trimethyl-ammonium bromide dissolved in $10 \mathrm{mM}$ potassium phosphate buffer $(\mathrm{pH} 7)$ and centrifuged for $30 \mathrm{~min}$ at $20,000 \times g$ at $4^{\circ} \mathrm{C}$. An aliquot of the supernatant was then allowed to react with a solution of $1.6 \mathrm{mM}$ tetra-methyl-benzidine and $0.1 \mathrm{mM}$ $\mathrm{H}_{2} \mathrm{O}_{2}$. The rate of change in absorbance was measured spectrophotometrically at $650 \mathrm{~nm}$. MPO activity was defined as the quantity of enzyme degrading $1 \mu \mathrm{mol}$ of peroxide at $37^{\circ} \mathrm{C}$ and was expressed as units of $\mathrm{MPO} / \mathrm{mg}$ of proteins.

Malondialdehyde measurement Malondialdehyde (MDA) levels, as an indicator of lipid peroxidation, were determined in the perilesional area of spinal cord tissue collected at $24 \mathrm{~h}$ after injury. Spinal cord tissue was weighed and homogenised in $1.15 \%(w / v) \mathrm{KCl}$ solution. An aliquot $(100 \mu \mathrm{l})$ of the homogenate was added to a reaction mixture containing $200 \mu \mathrm{l}$ of $8.1 \%(w / v)$ sodium dodecyl sulphate,

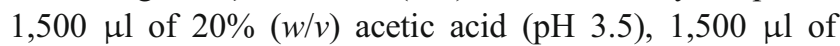
$0.8 \%(w / v)$ thiobarbituric acid and $700 \mu$ ldistilled water. Samples were then boiled for $1 \mathrm{~h}$ at $95^{\circ} \mathrm{C}$ and centrifuged at $3,000 \times \mathrm{g}$ for $10 \mathrm{~min}$. The absorbance of the supernatant was measured by spectrophotometry at $515-553 \mathrm{~nm}$.

Light microscopy Spinal cord biopsies were taken at $24 \mathrm{~h}$ following trauma. Tissue segments containing the lesion $(1 \mathrm{~cm}$ on each side of the lesion) were paraffin-embedded and cut into $5 \mu \mathrm{m}$-thick sections. Tissue sections (thickness $5 \mu \mathrm{m}$ ) were deparaffinized with xylene, stained with haematoxylin/eosin (H\&E) and studied using light microscopy (Dialux 22 Leitz, Milan, Italy). The segments of each spinal cord were evaluated by an experienced histopathologist. Damaged neurons were counted, and the histopathologic changes of the gray matter were scored on a six-point scale: 0 , no lesion observed; 1 ,gray matter contained one to five eosinophilic neurons; 2, gray matter contained five to ten eosinophilic neurons; 3 , gray matter contained more than ten eosinophilic neurons; 4, small infarction (less than one third of the gray matter area); 5, moderate infarction (one third to one half of the gray matter area); and 6, large infarction (more than half of the gray matter area). The scores from all the sections from each spinal cord were averaged to give a final score for individual mice. All the histologic studies were performed in a blinded fashion.

Immunohistochemical localization of nitrotyrosine, iNOS, poli (ADP-ribosio) (PAR), Bax and Bcl-2 Twenty-four hours after SCI, the tissues were fixed in $10 \%(w / v)$ phosphatebuffered saline (PBS)-buffered formaldehyde, and 8-mm sections were prepared from paraffin-embedded tissues. After deparaffinization, endogenous peroxidase was quenched with $0.3 \%(v / v)$ hydrogen peroxide in $60 \%(v / v)$ methanol for $30 \mathrm{~min}$. The sections were permeabilized with $0.1 \%(w / v)$ Triton X-100 in PBS for 20 min. Non-specific adsorption was minimised by incubating the section in $2 \%$ $(v / v)$ normal goat serum in PBS for 20 min. Endogenous biotin or avidin binding sites were blocked by sequential incubation for 15 min with biotin and avidin (DBA, Milan, Italy), respectively. Sections were incubated overnight with anti-nitrotyrosine rabbit polyclonal antibody (Ustate, 1:500 in PBS $v / v)$ with anti-iNOS polyclonal antibody rat (1:500 in PBS $v / v)$ anti-PAR antibody (1:200in PBS, $v / v)$, anti-Bax antibody (1:500 in PBS $v / v$ ), or with anti-Bcl-2 polyclonal antibody (Santa Cruz Biotechnology, DBA, Milan, Italy). Sections were washed with PBS and incubated with secondary antibody. Specific labelling was detected with a biotin-conjugated goat anti-rabbit $\operatorname{IgG}$ and avidin-biotin peroxidase complex. To verify the binding specificity for nitrotyrosine, iNOS, PAR, Bax and Bcl-2, some sections were also incubated with only the primary antibody (no secondary) or with only the secondary antibody (no primary). In these situations, no positive staining was found in the sections, indicating that the immuno reaction was positive in all the experiments carried out.

Subcellular fractionation, nuclear protein extraction and Western blot analysis Tissues were homogenised in cold lysis buffer $(0.32 \mathrm{M}$ Sucrose, $10 \mathrm{mM}$ Tris- $\mathrm{HCl} \mathrm{pH}$ 7.4, $1 \mathrm{mM}$ ethyleneglycoltetraacetic acid (EGTA), $2 \mathrm{mM}$ ethylendiaminetetraacetic acid (EDTA), $5 \mathrm{mM} \mathrm{NaN}_{3}$, $10 \mathrm{mM} \beta$-mercaptoethanol, $20 \mu \mathrm{M}$ leupeptin, $0.15 \mu \mathrm{M}$ pepstatin A, $0.2 \mathrm{mM}$ phenylmethylsulphonyl fluoride (PMSF), $50 \mathrm{mM} \mathrm{NaF}, 1 \mathrm{mM}$ sodium orthovanadate, $0.4 \mathrm{nM}$ microcystin). Homogenates were centrifuged at $1,000 \times g$ for $10 \mathrm{~min}$ at $4^{\circ} \mathrm{C}$, and the supernatant (cytosol + membrane extract) was collected to evaluate contents of Phospho-NFkBp65 (ser536), iNOS, IkB- $\alpha$, Bax, Bcl-2 and $\beta$-actin. The pellet were solubilised in Triton buffer $(1 \%$ 

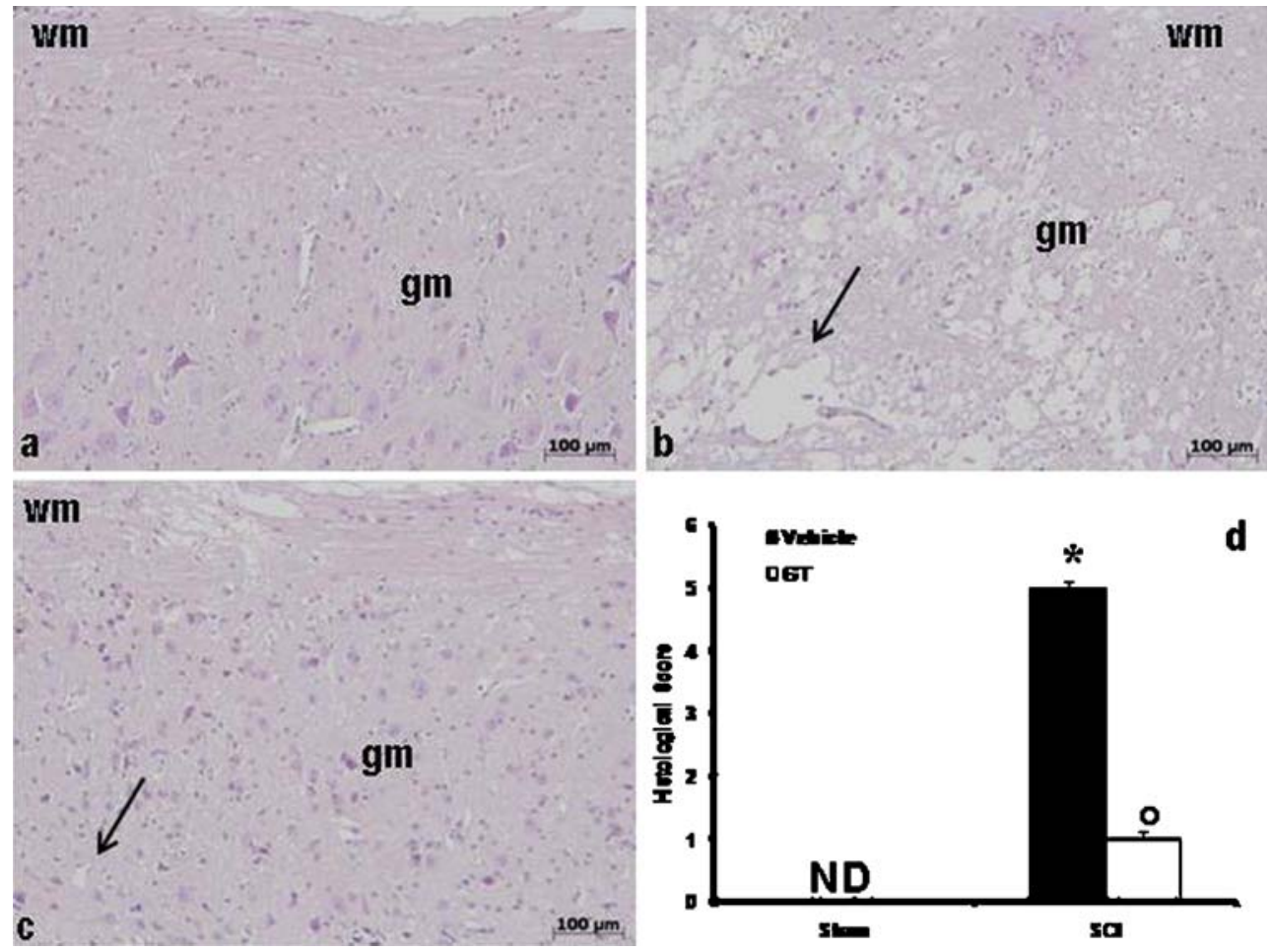

Fig. 1 Effect of GTE treatment on histological alterations of the spinal cord tissue $24 \mathrm{~h}$ after injury. The severity of the trauma was evaluated at $24 \mathrm{~h}$ after injury and stained with H\&E. No histological alterations were observed in the spinal cord tissues from shamoperated mice (a). Twenty-four hours after trauma, a significant damage to the spinal cord from untreated SCI-operated mice at the perilesional area was assessed by the presence of oedema as well as alteration of the white matter (b). It is noteworthy that a significant

Triton-X-100, $150 \mathrm{mM} \mathrm{NaCl}, 10 \mathrm{mM}$ Tris- $\mathrm{HCl} \mathrm{pH} 7.4$, $1 \mathrm{mM}$ EGTA, $1 \mathrm{mM}$ EDTA, $0.2 \mathrm{mM}$ sodium orthovanadate, $20 \mu \mathrm{M}$ leupeptin, $0.2 \mathrm{mM}$ PMSF) and centrifuged at $15,000 \times \mathrm{g}$ or $30 \mathrm{~min}$ at $4^{\circ} \mathrm{C}$, and the supernatant (nuclear extract) was collected to evaluate the content of NF-kB p65 protection from the SCI was observed in the tissue collected from GTE-treated SCI-injured mice (c). The histological score (d) was made by an independent observer. This figure is representative of at least three experiments performed on different experimental days. $\mathrm{wm}$ white matter, $g m$ gray matter. Values shown are mean \pm SE mean of ten mice for each group. ${ }^{*} p<0.01$ versus Sham, degree symbol $p<0.01$ versus SCI

and $\beta$-actina. Protein concentration in homogenate was determined by Bio-Rad Protein Assay (BioRad, Richmond CA, USA), and $50 \mu \mathrm{g}$ of cytosol and nuclear extract from each sample was analysed. Proteins were separated by a $12 \%$ sodium dodecyl sulphate-polyacrylamide gel electro-

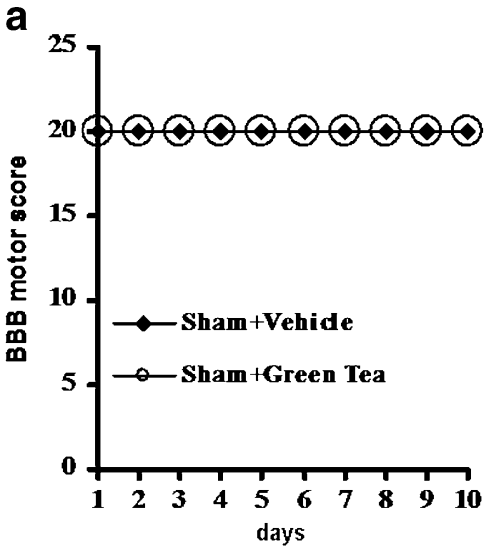

Fig. 2 Effect of GTE extract on hind limb motor disturbance after spinal cord injury. The degree of motor disturbance was assessed every day until 10 days after SCI, by Basso, Beattie and Bresnahan b

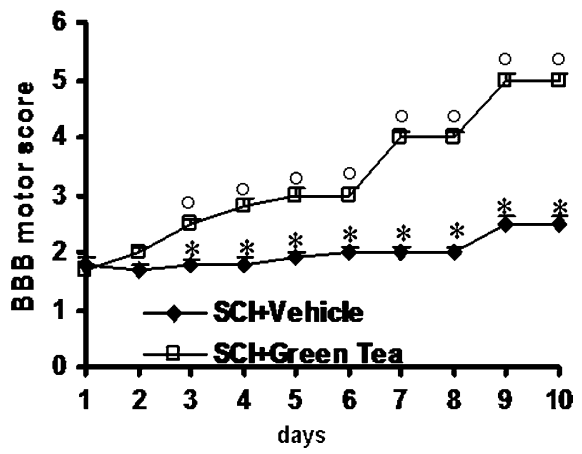

criteria. Treatment with GTE reduces the motor disturbance after SCI $(\mathbf{a}, \mathbf{b})$. Values shown are mean $\pm \mathrm{SE}$ mean of ten mice for each group. $*_{p}<0.01$ versus Sham, degree symbol $p<0.01$ versus SCI 
phoresis and transferred on polyvinylidene difluoride membrane (Hybond-P Nitrocellulose, Amsherman Biosciences, UK). The membrane was blocked with $0.1 \%$ Tris-buffered saline (TBS)-Tween containing 5\% non fat milk for $1 \mathrm{~h}$ at room temperature. After the blocking, the membranes were incubated with the relative primary antibody overnight at $4{ }^{\circ} \mathrm{C}$; anti-phospho-NF-kB p65 (ser536) Rabbit mAb diluited 1:1,000 (Cell Signalling technology, USA), anti-iNOS TYPE II diluted 1:2,000 (Transduction Laboratories), anti-IkB- $\alpha$ diluted 1:2,000, anti-Bax diluted 1:500, anti-Bcl2 diluted 1:500, anti-NF-kB p65 diluited 1:500. After the incubation, the membranes were washed three times for $10 \mathrm{~min}$ with $0.1 \%$ TBS-Tween and were incubated for $1 \mathrm{~h}$ with peroxidase- conjugated anti-mouse or anti-rabbit secondary antibodies (Jackson ImmunoResearch Laboratories, USA) diluted 1:2,000; the membranes were washed three times for $10 \mathrm{~min}$, and protein bands were detected with SuperSignal West Pico Chemioluminescent (PIERCE). Densitometry analysis was performed with a quantitative imaging system.

Measurement of TNF- $\alpha$ and il-1 $\beta$ concentration Portions of spinal cord tissue, collected $24 \mathrm{~h}$ after SCI, were homogenised as previously described in PBS containing $2 \mathrm{mmol} / \mathrm{L}$ of PMSF (Sigma Chemical), and tissue TNF- $\alpha$ and IL-1 $\beta$ levels were evaluated. The assay was carried out

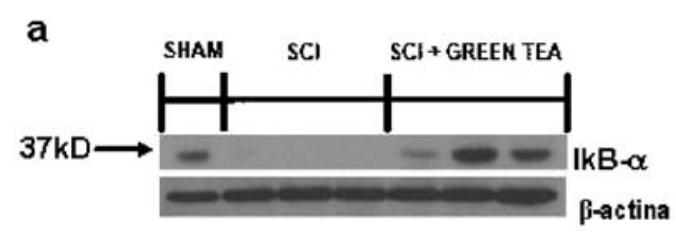

a1
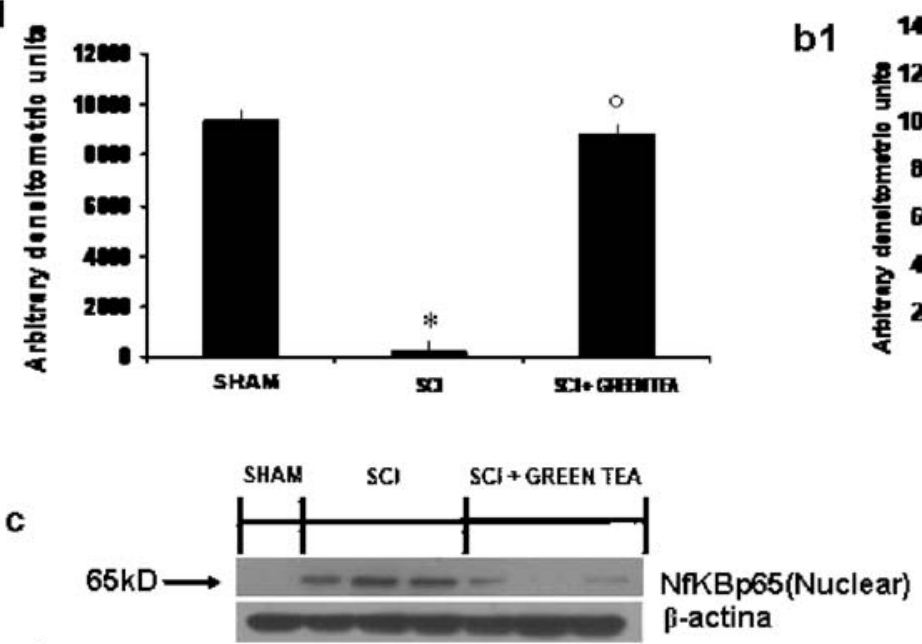

c1

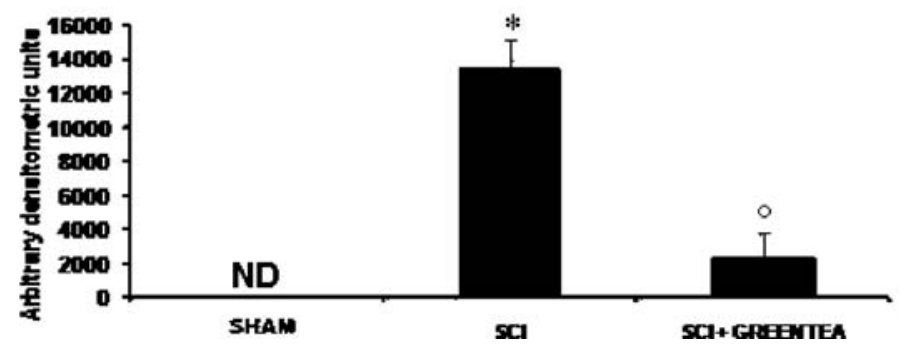

Fig. 3 Effects of GTE treatment on IkB- $\alpha$ degradation, phosphorylation of NF-kB subunit $\mathrm{p} 65$ on Ser 536 and nuclear NF-kB p65. By Western blot analysis, a basal level of $\mathrm{I} k B-\alpha$ was detected in the spinal cord from sham-operated animals $(\mathbf{a}, a 1)$, whereas in SCI control mice, I kB- $\alpha$ levels were substantially reduced (a, al). GTE treatment prevented the SCI-induced I kB- $\alpha$ degradation $(\mathbf{a}, a 1)$. In addition, SCI caused a significant increase in the phosphorylation of Ser536 at $24 \mathrm{~h}(\mathbf{b}, b 1)$. The treatment with GTE significantly reduced the phosphorylation of p65 on Ser536 $(\mathbf{b}, b 1)$. Moreover, the levels of

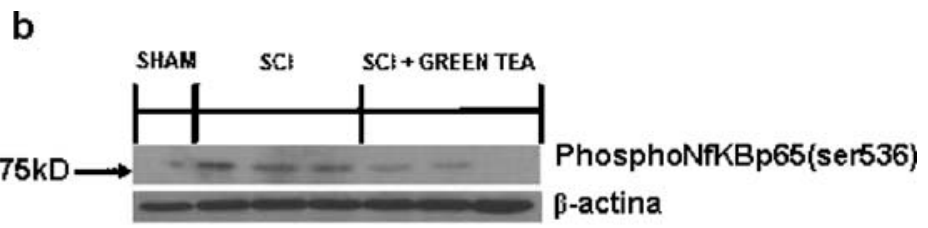

b1

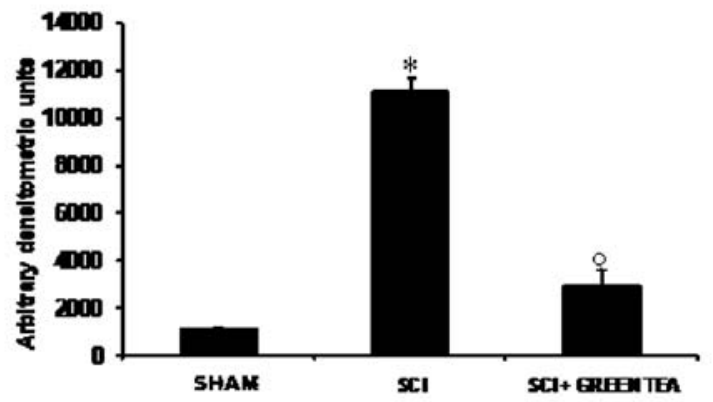

the NF-kB p65 subunit protein in the nuclear fractions of the spinal cord tissue were also significant increased at $24 \mathrm{~h}$ after SCI compared with the sham-operated mice $(\mathbf{c}, c 1)$. The levels of NF-kB p65 protein were significantly reduced in the nuclear fractions of the spinal cord tissues from animals that had received GTE treatment as shown in c (c1). Immunoblotting in $\mathbf{a}-\mathbf{c}$ are representative of one spinal cord of five analysed. The results in $a 1, b 1$ and $c l$ are expressed as mean $\pm \mathrm{SE}$ mean from five blots. ${ }^{*} p<0.01$ versus Sham, degree symbol $p<0.01$ versus SCI 
Fig. 4 Effect of GTE on TNF- $\alpha$ and IL- $1 \beta$ release and on MPO activity. A substantial increase in TNF- $\alpha$ (a) and IL-1 $\beta$ (b) production was found in spinal cord tissue collected from SCI mice at $24 \mathrm{~h}$. Spinal cord levels of TNF- $\alpha$ and IL- $1 \beta$ were significantly attenuated by the green tea treatment $(\mathbf{a}, \mathbf{b})$. Moreover, MPO activity in spinal cord of untreated SCIoperated mice was significantly increased at $24 \mathrm{~h}$ after the damage in comparison to sham mice (c). Treatment with GTE significantly reduced the SCIinduced increase in MPO activity (c). Data are means $\pm \mathrm{SE}$ mean of ten mice for each group. ${ }^{*} p<0.01$ versus Sham, degree symbol $p<0.01$ versus SCI a

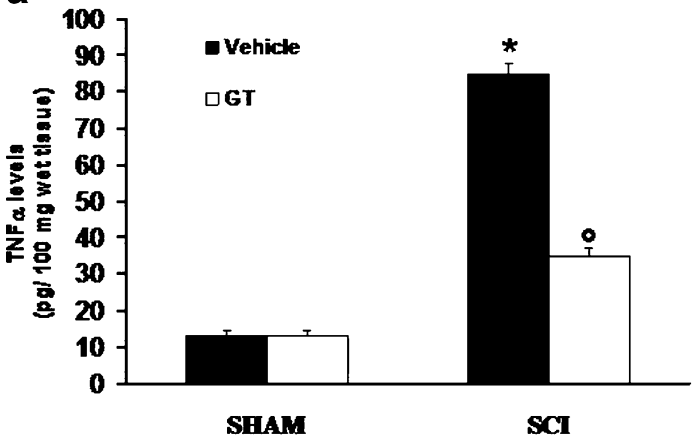

C

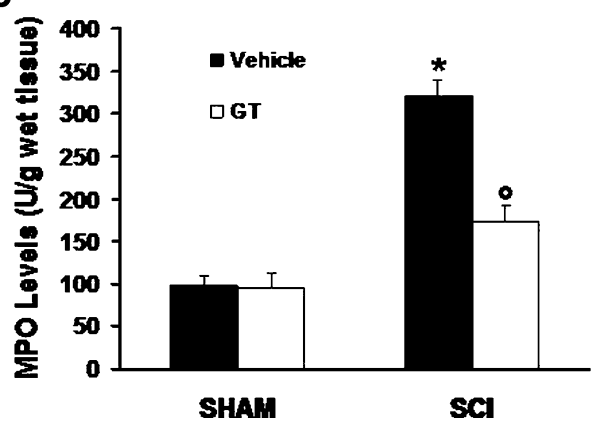

b

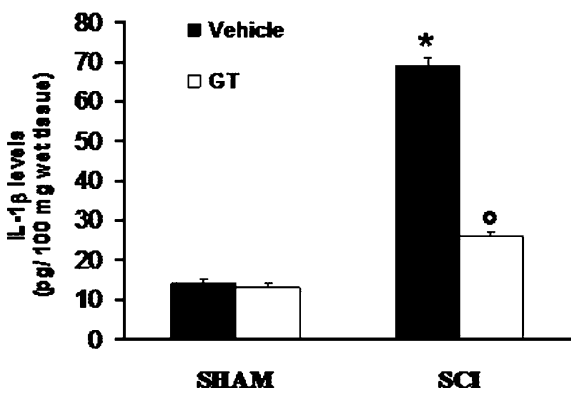

by using a colorimetric, commercial enzyme-linked immunosorbent assay kit (Calbiochem-Novabiochem Corporation, Milan, Italy) according to the manufacturer's instructions. All TNF- $\alpha$ and IL- $1 \beta$ determinations were performed in duplicate serial dilutions.

Grading of motor disturbance The motor function of mice subjected to compression trauma was assessed daily for 10 days after injury. Recovery from motor disturbance was graded using the modified murine Basso, Beattie and Bresnahan (BBB) (Basso et al. 1995) hind limb locomotors rating scale (Joshi and Fehlings 2002).

Materials Unless otherwise stated, all compounds were obtained from Sigma-Aldrich Company (Milan, Italy). All stock solutions were prepared in nonpyrogenic saline $(0.9 \%$ $\mathrm{NaCl}$; Baxter, Italy, UK).

Statistical evaluation All values in the figures and text are expressed as mean \pm standard error of the mean (SEM) of $N$ observations. For the in vivo studies, $N$ represents the number of animals studied. In the experiments involving histology or immunohistochemistry, the figures shown are representative of at least three experiments performed on different experimental days. The results were analysed by one-way analysis of variance followed by a Bonferroni post hoc test for multiple comparisons. A $p$ value of less than 0.05 was considered significant. BBB scale data were analysed by the Mann-Whitney test and considered significant when $p$ value was $<0.05$.

\section{Results}

Green tea extract reduces the severity of spinal cord trauma The severity of the trauma at the level of the perilesional area, assessed as the presence of oedema as well as alteration of the white matter (Fig. 1), was evaluated at $24 \mathrm{~h}$ after injury and stained with $\mathrm{H} \& \mathrm{E}$ (an immunohistological staining). A significant damage to the spinal cord was observed in the spinal cord tissue from SCI mice (Fig. 1b) when compared with Sham-operated mice

Fig. 5 Effects of GTE on iNOS expression. iNOS expression was evaluated by both Western Blot analysis and immunohistochemical analysis. By Western blot analysis, a basal level of iNOS was detected in the spinal cord from Sham-operated mice (a, al). iNOS levels were appreciably increased in the spinal cord from control mice subjected only to SCI. On the contrary, green tea treatment prevented the SCIinduced iNOS expression (a, al). In addition, iNOS expression was also evaluated by immunoistochemical analysis in the spinal cord section $24 \mathrm{~h}$ after SCI. Spinal cord section from sham-operated mice did not stain for iNOS (b), whereas spinal cord section obtained from SCI-operated mice exhibited positive staining for iNOS (c, $c 1)$ mainly localised in various inflammatory cells in the gray matter. GTE treatment reduced the degree for positive staining for iNOS in the spinal cord tissue (d). Densitometry analysis of immunocytochemistry photographs ( $n=5$ photos from each sample collected from all mice in each experimental group) for iNOS (e) from spinal cord tissues was assessed. The assay was carried out by using Optilab Graftek software on a Macintosh personal computer (CPU G3-266). Data are expressed as percent of total tissue area. $w m$ white matter, $g m$ gray matter. This figure is representative of at least three experiments performed on different experimental days. ${ }^{*} p<0.01$ vs. Sham. Degree symbol $p<$ 0.01 vs SCI+vehicle 

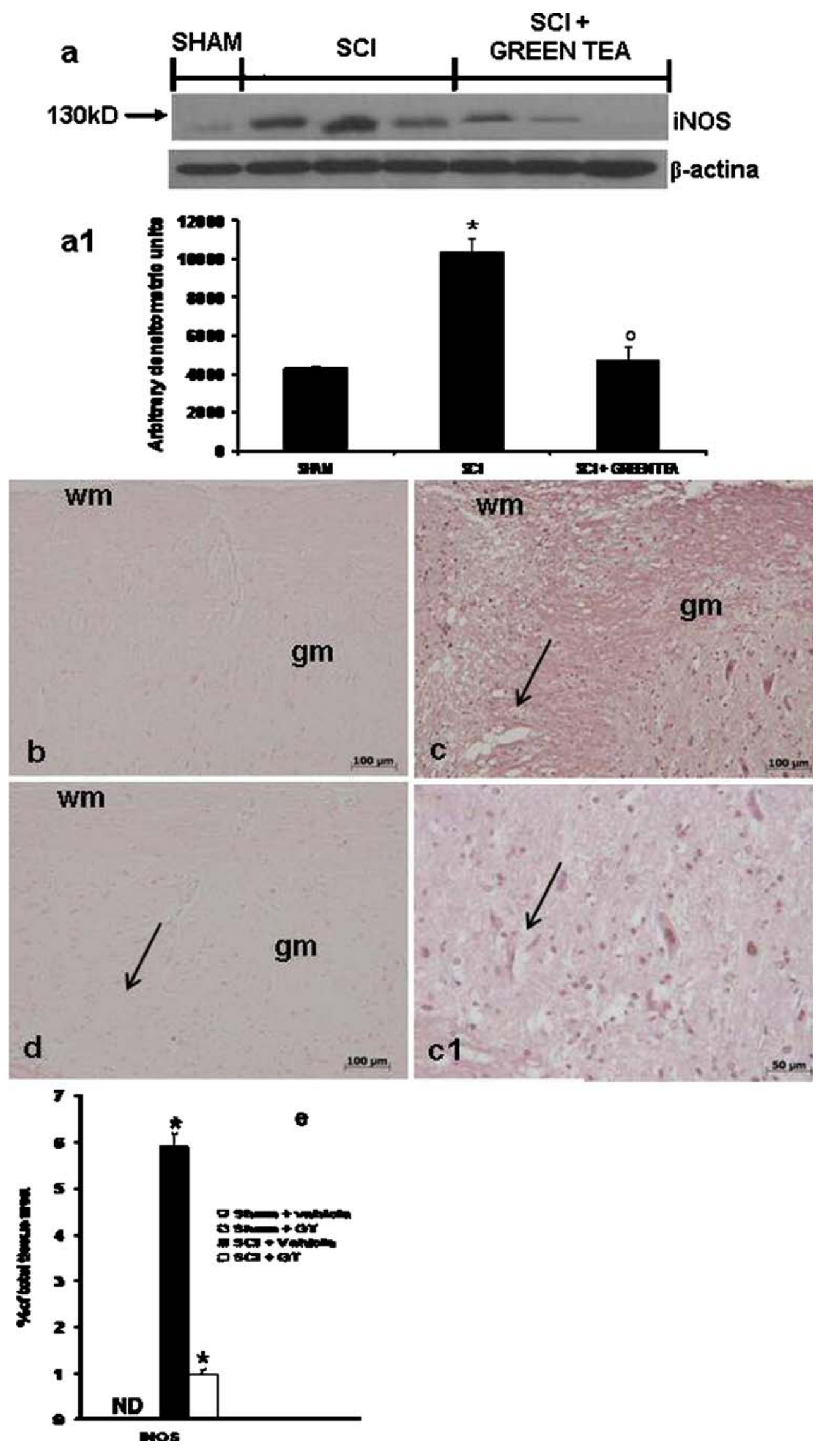
(Fig. 1a). It is noteworthy that a significant protection against the SCI was observed in green tea-treated mice (Fig. 1c). To evaluate whether histological damage to the spinal cord was associated with a loss of motor function, the modified $\mathrm{BBB}$ hind limb locomotor rating scale score was evaluated. Whereas motor function was only slightly impaired in Sham mice (Fig. 2a), mice subjected to SCI had significant deficits in hind limb movement (Fig. 2b). A significant amelioration of hind limb motor disturbances was observed in green tea-treated mice (Fig. 2b)

Effect of green tea on IkB $\alpha$ degradation, phosphorylation of $p 65$ on Ser536, NF- $k \beta$ p 65 Most inflammatory mediators, including iNOS, IL- $1 \beta$ and TNF- $\alpha$, are controlled by $\mathrm{NF}-\mathrm{kB}$, a transcription factor important in inflammatory process, which is kept inactive by IkB (La Rosa et al. 2004). By Western blot analysis, we evaluated both IkB- $\alpha$ degradation and phosphorylation of Ser536 on the NF-kB subunit p65 and on total NF-kB p65 to investigate the cellular mechanisms by which treatment with green tea may attenuate the development of SCI. A basal level of IkB- $\alpha$ was detected in the spinal cord sample from Sham-operated animals (Fig. 3a, a1), whereas in SCI control mice, $\mathrm{IkB} \alpha$ levels were substantially reduced (Fig. 3a, a1). Green tea treatment prevented the SCI-induced IkB- $\alpha$ degradation, and the IkB- $\alpha$ levels remained unchanged $24 \mathrm{~h}$ after SCI (Fig. 3a, a1) in green tea-treated mice.

In addition, SCI caused a significant increase in the phosphorylation of Ser536 at $24 \mathrm{~h}$. The treatment with green tea significantly reduced the phosphorylation of p65 on Ser536 (Fig. 3b, b1).

Moreover, the levels of the NF-kB p65 subunit protein in the nuclear fractions of the spinal cord tissue were also significantly increased at $24 \mathrm{~h}$ after SCI compared with the Sham-operated mice.

Green tea treatment significantly reduced the levels of NF-kB p65 protein as shown (Fig. 3c, c1).

Green tea extract modulates expression of TNF- $\alpha$ and IL$1 \beta$ and neutrophil infiltration after SCI To test whether green tea modulates the inflammatory process trough the regulation of secretion of pro-inflammatory cytokines, we analysed the spinal cord levels of TNF- $\alpha$ (Fig. 4a) and IL-1 $\beta$ (Fig. 4b). A substantial increase in TNF- $\alpha$ (Fig. 4a) and IL$1 \beta$ (Fig. 4b) production was found in spinal cord tissue collected from SCI mice at $24 \mathrm{~h}$. Spinal cord levels of TNF$\alpha$ and IL- $1 \beta$ were significantly attenuated by the green tea treatment (Fig. 4a, b)

The histological pattern of spinal cord injury seemed to be correlated with the influx of leukocytes into the spinal cord. Therefore, we investigated the effect of extract of green tea on the neutrophilic infiltration by measuring tissue MPO activity (Fig. 4c). MPO activity was significantly elevated in the spinal cord at $24 \mathrm{~h}$ after injury in mice subjected to SCI when compared with Sham-operated mice. In green tea-treated mice, the MPO activity in the spinal cord at $24 \mathrm{~h}$ after injury was significantly attenuated in comparison to that observed in SCI controls.

Green tea modulates expression of iNOS after SCI To determine the role of nitric oxide (NO) produced during SCI, iNOS expression was evaluated both Western Blot analysis and immunohistochemical analysis. At $24 \mathrm{~h}$ after SCI, iNOS activity was investigated by Western blot analysis in homogenate tissue of spinal cord. A basal level of iNOS was detected in the spinal cord from Shamoperated mice (Fig. 5a, a1). iNOS levels were appreciably increased in the spinal cord from control mice subjected only to SCI. On the contrary, green tea treatment ( 1 and $6 \mathrm{~h}$ after SCI induction) prevented the SCI iNOS expression (Fig. 5a, a1).

iNOS expression was evaluated by immuno-histochemical analysis. Spinal cord sections obtained from Sham-operated mice did not stain for iNOS (Fig. 5b, see densitometry analysis in Fig. 5e), whereas spinal cord section obtained from mice subject to SCI exhibited positive staining for iNOS (Fig. 5c, see particle c1, and see densitometry analysis in Fig. 5e) localised in inflammatory cells as well as in nuclei of Schwann cells in the white and gray matter of the spinal cord tissues. Green tea treatment reduced the degree of positive staining for iNOS (Fig. 5d, see densitometry analysis in Fig. 5e).

Effects of green tea on nitrotyrosine formation, lipid peroxidation and PAR formation after SCI The influences of green tea on the extent of posttraumatic oxidative stress induced by SCI were investigated at $24 \mathrm{~h}$ after SCI

SCI is associated to a significant increase of the MDA levels, indicating lipid peroxidation in the injured tissue (Fig. 6a). The treatment with green tea caused a significant reduction of the MDA levels in the injured tissue. No significant lipid peroxidation was observed in the Shamoperated mice.

Twenty-four hours after SCI, nitrotyrosine, a specific marker of nitrosative stress, was measured by immunohistochemical analysis in the spinal cord sections to determine the localization of "peroxynitrite formation" and/or other nitrogen derivatives produced during SCI. Sections of spinal cord from Sham-operated mice did not stain for nitrotyrosine (Fig. $6 \mathrm{~b}$ and see densitometry analysis in Fig. $6 \mathrm{~b}(\mathrm{~g}))$, whereas spinal cord sections obtained from SCI control mice exhibited positive staining for, nitrotyrosine (Fig. 6b(b), see particle (b1), and see densitometry analysis in Fig. $6 \mathrm{~b}(\mathrm{~g}))$. The positive staining was mainly localised in inflammatory cells as well as in nuclei of Schawnn cells in 
Fig. 6 Effect of GTE on lipidic peroxidation, nitrotyrosine formation and PARP formation.

The MDA levels were significantly increased in the spinal cord tissues from SCI operated mice (a). GTE reduced the spinal cord injury-induced increase in MDA levels (a). Spinal cord section from sham-operated mice did not stain for nitrotyrosine $(\mathbf{b}, a)$. In addition, section obtained from SCI animals demonstrated positive staining for nitrotyrosine mainly localised in inflammatory cells and in the nuclei of Schawnn cells in the wite and gray matter $(\mathbf{b}, b$, b1). GTE treatment reduced the degree for positive staining for nitrotyrosine in the spinal cord tissue $(\mathbf{b}, c)$. Moreover, immunoistrochemistry for PAR revealed the occurrence of positive staining for PAR in mice subject to SCI $(\mathbf{b}, e)$. GTE treatment reduced the degree for positive staining for PAR in the spinal cord tissue $(\mathbf{b}, f)$. No positive staining for PAR was observed in the tissue section from sham-operated $(\mathbf{b}, d)$. Densitometry analysis of immunocytochemistry photographs $(n=$ 5 photos from each sample collected from all mice in each experimental group) for nitrotyrosine and PAR $(\mathbf{b}, g)$ from spinal cord tissues was assessed. The assay was carried out by using Optilab Graftek software on a Macintosh personal computer (CPU G3-266). Data are expressed as percent of total tissue area. Values shown are mean \pm SE mean of ten rats for each group. $w m$ white matter, $g m$ gray matter. This figure is representative of at least three experiments performed on different experimental days. ${ }^{*} p<0.01$ versus sham, e, degree symbol $p<$ 0.01 versus SCI a

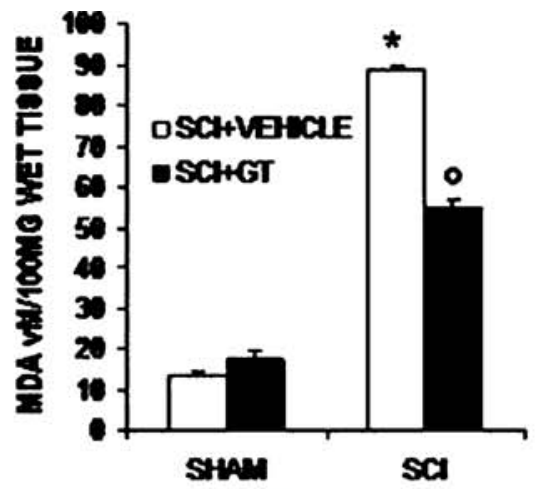

b
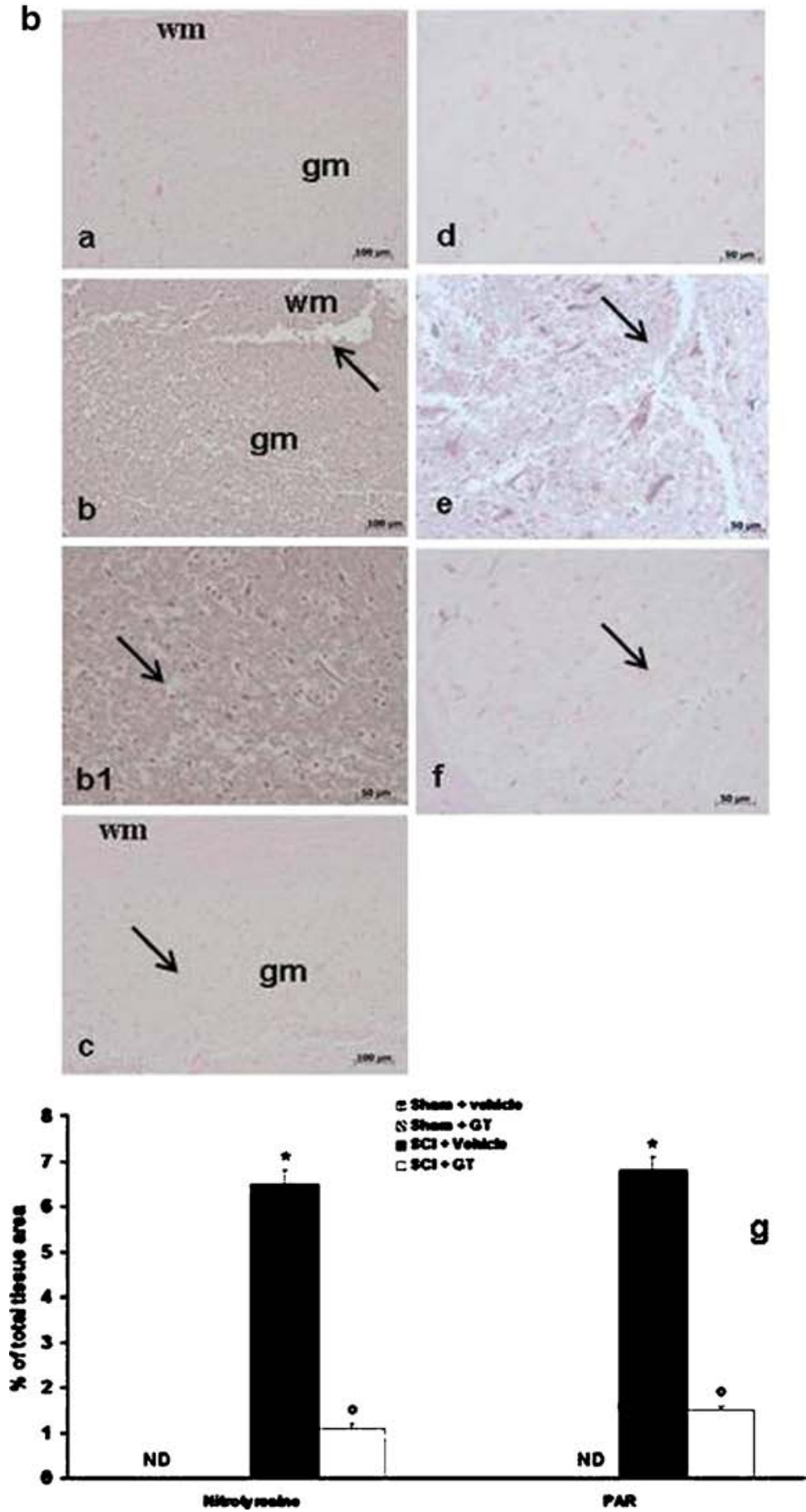
the white and gray matter of spinal cord. Green tea treatment ( 1 and $6 \mathrm{~h}$ after SCI induction) of mice subjected to SCI reduced the degree of positive staining for nitrotyrosine (Fig. 6b(c), see densitometry analysis in Fig. 6b (g)), in the spinal cord. Sections of the spinal cord were taken at the same hour after SCI in order to determine the activation of the nuclear enzyme poly(ADP-ribose) polymerase that has been implicated in the pathogenesis of spinal cord injury. Thus, we used an immunohistochemical approach to assess the presence of PAR, as an indicator of in vivo PARP activation. There was positive staining for PAR localised in nuclei of schawnn cells in the white matter of spinal cord tissue from mice subject to SCI (Fig. 6b(e), see densitometry analysis in Fig. $6 \mathrm{~b}(\mathrm{~g}))$. Green tea treatment reduced the degree of positive staining for PAR (Fig. 6b(f), see densitometry analysis in Fig. 6b(g)) in spinal cord. No positive staining for PAR has been found in the spinal cord from Sham-operated mice (Fig. 6c(d), see densitometry analysis in Fig. 6b(g)).

Western blot analysis and immunohistochemistry for Bax and $\mathrm{Bcl}-2$ At $24 \mathrm{~h}$ after SCI, the appearance of Bax in spinal cord homogenates was investigated by Western blot. Bax levels were appreciably increased in the spinal cord from control mice subjected to SCI (Fig. 7a(a), a1). On the contrary, green tea treatment ( 1 and $6 \mathrm{~h}$ after SCI induction) prevented the SCI-induced Bax expression (Fig. 7a(a), a1).

By Western blot analysis, we also analysed whole extracts from spinal cord of each mouse to detect Bcl-2 expression. Twenty-four hours after SCI, the Bcl-2 expression was significantly reduced in whole extracts obtained from Spinal cord of SCI control mice (Fig. 7a(b), b1). Treatment of mice with green tea significantly reduced the SCI-induced inhibition of Bcl-2 expression (Fig. 7a(b), b1).

Moreover, samples of spinal cord tissue were taken at $24 \mathrm{~h}$ after SCI to determine the immuno-histological staining for Bax and Bcl-2. Sections of spinal cord from sham-operated mice did not stain for Bax (Fig. 7b(a), see densitometry analysis in Fig. $7 \mathrm{~b}(\mathrm{~g})$ ), whereas spinal cord sections obtained from SCI control mice exhibited a positive staining for Bax (Fig. $7 b(b)$, see particle b1, and see densitometry analysis in Fig. $7 \mathrm{~b}(\mathrm{~g}))$. Green tea treatment reduced the degree of positive staining for Bax in the spinal cord of mice subjected to SCI (Fig. $7 b(c)$, see densitometry analysis in Fig. $7 \mathrm{~b}(\mathrm{~g})$ ).

In addition, spinal cord sections from sham-operated mice demonstrated Bcl-2 positive staining (Fig. $7 \mathrm{~b}(\mathrm{~d}$ ), see densitometry analysis in Fig. $7 \mathrm{~b}(\mathrm{~g})$ ), whereas in SCI control mice, the staining significantly reduced (Fig. $7 b(e)$ see densitometry analysis in Fig. $7 \mathrm{~b}(\mathrm{~g})$ ). Green tea treatment attenuated the loss of positive staining for $\mathrm{Bcl}-2$ in the spinal cord from SCI-subjected mice (Fig. $7 b(f)$, see densitometry analysis in Fig. $7 \mathrm{~b}(\mathrm{~g}))$.

\section{Discussion}

An excessive post-traumatic inflammatory reaction may play an important role in the secondary injury processes, which develop after spinal cord injury. The primary traumatic mechanical injury to the spinal cord causes the death of a number of neurons that to date can neither be recovered nor regenerated. However, neurons continue to die for hours after spinal cord injury, and this represents a potentially avoidable event (Amar and Levy 1999). This secondary neuronal death is determined by a large number of cellular, molecular, and biochemical cascades. One such cascade that has been proposed to contribute significantly to the evolution of the secondary damage is the local inflammatory response in the injured spinal cord. Recent evidence, however, suggests that leukocytes, especially neutrophils which are the first leukocytes to arrive within the injured spinal cord (Carlson et al. 1998) may also be directly involved in the pathogenesis and extension of spinal cord injury in rats. Several authors have demonstrated that neutrophils are especially prominent in a 'marginal zone' around the main area of injury and infarction at $24 \mathrm{~h}$ (de Castro et al. 2004). This study provides the first evidence that GTE attenuates at $24 \mathrm{~h}$ after SCI: the degree of spinal cord damage, the infiltration of the spinal cord with PMNs, NF-kB activation, iNOS expression, nitro-

Fig. 7 Effects of GTE treatment on Bax and Bcl-2 levels. Representative Western blot of Bax levels and Bcl-2 was realised in spinal cord tissue collected at $24 \mathrm{~h}$ after injury. A basal level of Bax was present in the tissue from sham-operated mice (a, a, al). Bax band is more evident in the tissue from spinal cord-injured mice (panel A a, a1). Bax band disappeared in the tissue from spinal cord-injured mice that received GTE treatment (a, $a, a 1)$. Moreover, a basal level of $\mathrm{Bcl}-2$ was present in the tissue from sham-operated mice $(\mathbf{a}, b, b 1)$. Bcl-2 band disappeared in the tissue from spinal cord-injured mice (a, $b, b 1)$. Bcl-2 band is more evident in the tissue from spinal cordinjured mice that received GTE treatment $(\mathbf{a}, b, b 1)$. The results are expressed as mean $\pm \mathrm{SE}$ mean from five blots. Moreover, Bax and Bcl2 expression was also evaluated by immunoistochemical analysis in the spinal cord section at $24 \mathrm{~h}$ after SCI. Spinal cord section from sham-operated mice did not stain for $\operatorname{Bax}(\mathbf{b}, a)$, whereas spinal cord section obtained from SCI-operated mice exhibited positive staining for $\operatorname{Bax}(\mathbf{b}, b, b 1)$. GTE treatment reduced the degree for positive staining for Bax in the spinal cord tissue $(\mathbf{b}, c)$ of mice subject to SCI. In addition, spinal cord section from sham-operated mice demonstrated Bcl-2 positive staining $(\mathbf{b}, d)$, while in SCI control mice, the staining significantly reduced $(\mathbf{b}, e)$. GTE treatment attenuated the loss of positive staining for Bcl-2 in the spinal cord tissue $(\mathbf{b}, f)$ from SCIsubject mice. Densitometry analysis of immunocytochemistry photographs ( $n=5$ photos from each sample collected from all mice in each experimental group) for Bax and Bcl-2 (b, g) from spinal cord tissues was assessed. The assay was carried out by using Optilab Graftek software on a Macintosh personal computer (CPU G3-266). Data are expressed as $\%$ of total tissue area. $w m$ white matter, gm gray matter. This figure is representative of at least three experiments performed on different experimental days. ${ }^{*} p<0.01$ vs. Sham. Degree symbol $p<$ 0.01 vs SCI + vehicle 

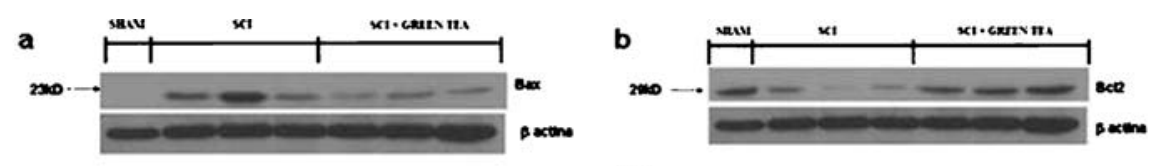

A
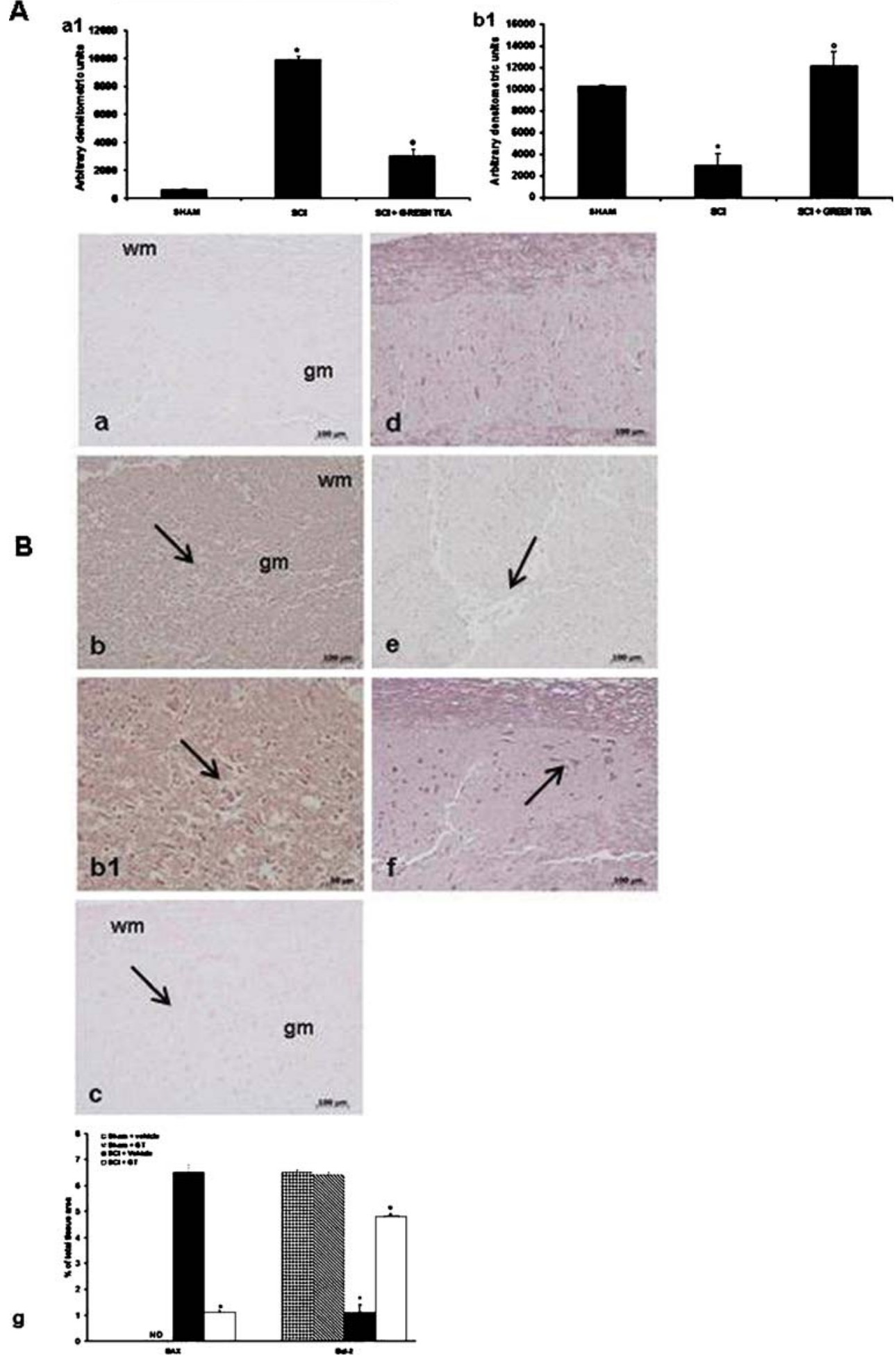
tyrosine formation, activation of the nuclear enzyme PARP and the degree of apoptosis. All of these findings support the view that GTE attenuates the degree of acute inflammation in the mouse due to SCI.

What, then, is the mechanism by which GTE protects against inflammatory injury?

GTE is rich in powerful anti-oxidant compounds called polyphenols. The polyphenols found in tea are more commonly known as flavanols or catechins. EGCG is a major catechin present in green tea. Pharmacological functions of catechines have been studied, including protection against coronary heart disease (Townsend et al. 2004), various types of cancer (Ogata et al. 1995) and inflammatory diseases. The anti-oxidant properties of EGCG have attracted considerable attention for the prevention of oxidative stress-related diseases.

Spinal cord trauma, induced by the application of vascular clip to the dura via, a four-level T5-T8 laminectomy, resulted in oedema and tissue injury in lateral and dorsal funiculi. The histological damage was associated with a loss of motor function. In this report, we demonstrated that green tea exerts beneficial effects to the degree of spinal cord damage and ameliorates the hind limb motor disturbances. SCI initiates a sequence of events that lead to secondary neuronal cell damage. While the precise mechanisms responsible to damage in SCI remain undefined, several studies have implicated ROS in the secondary neuronal damage of SCI (Liu et al. 1997; Xu et al. 2001). ROS and peroxynitrite also cause DNA damage (Salgo et al. 1995; Szabo et al. 1997, 1998). The finding that reactive oxygen radicals are generated following injury also suggests that green tea may act as a free-radical scavenger to mediate its anti-oxidant and neuroprotective effects.

It is known that following SCI there was a significant increase not only for free radical species but also for lipid peroxidation. Malondialdehyde levels, as an indicator of lipid peroxidation, were determined in the spinal cord tissue. In this study, we demonstrated that the treatment with GTE caused a significant reduction of the MDA levels in the injured tissue. No significant lipid peroxidation was observed in the Sham-operated mice.

Peroxynitrite, one of a number of toxic factors produced in the spinal cord tissues after SCI (Liu et al. 2000; Scott et al. 1999; Xu et al. 2001), likely contributes to secondary neuronal damage through pathways resulting from the chemical modification of cellular proteins and lipids. To probe the pathological contributions of peroxynitrite to secondary damage after SCI, we have used the appearance of nitrotyrosine staining in the inflamed tissue. We have observed in this present study that the immunoassaying of nitrotyrosine is reduced in SCI operated mice treated with GTE when compared with SCI operated mice.
Nitrotyrosine formation, along with its detection by immunostaining, was initially proposed as a relatively specific marker for the detection of the endogenous formation "footprint" of peroxynitrite (Beckman 1996). There is, however, recent evidence that certain other reactions can also induce tyrosine nitration; e.g. the reaction of nitrite with hypochlorous acid and the reaction of myeloperoxidase with hydrogen peroxide can lead to the formation of nitrotyrosine (Endoh et al. 1994). Increased nitrotyrosine staining is considered, therefore, as an indication of "increased nitrosative stress" rather than a specific marker of the peroxynitrite generation.

Damage may also induce inflammation and further generation of reactive oxygen and nitrogen species (RONS) by immunocytes and microglia (Akiyama et al. 2000). On initial SCI, resident macrophages become activated and secrete proinflammatory mediators, resulting in recruitment of neutrophils like our other studies demonstrated (Genovese et al. 2005a, c; La Rosa et al. 2004; Scott et al. 2005). This is followed by a second wave of response to localise the inflammatory response to within the spinal cord tissue and to down modulate this response. In SCI operated mice not treated with GTE, the decreased activity of down modulation results in persistent neutrophil infiltrate, as assessed by measurement of levels of the specific granulocyte enzyme MPO and in more severe tissue damage, as evaluated by histological examination.

Recent evidence suggests that NF-kB plays a central role in the regulation of many genes responsible for the generation of mediators or proteins in secondary inflammation associated to SCI. Under normal conditions, NF-kB is present within the cytoplasm in an inactive state, bound to its inhibitory protein IkB- $\alpha$. However, an inflammatory stimulation initiates the phosphorylation of IkB- $\alpha$ on serine residues 32 and 36 by IkB kinase. Once liberated from its inhibitory protein, NF-kB translocates to the nucleus, where it orchestrates the transcription of a number of proinflammatory genes (Peters et al. 2000). In addition, there are numerous reports which point out that phosphorylation of NF-kB p65 might also have relevant role in the activation of NF-kB as well as in the understanding the role of this transcription factor. The exact mechanisms by which GTE can suppress NF-kB activation in inflammation and posttraumatic injury is not completely known. However, the results of this study demonstrate that GTE treatment inhibits the IkB- $\alpha$ degradation as well as the NF-kB activation.

Moreover, after SCI, the expression of pro-inflammatory cytokines at the site of injury regulates the precise cellular events that lead to secondary injury. In this study, we documented increased production of both TNF- $\alpha$ and IL$1 \beta$ after SCI. Remarkably, there was no increase in the expression of either TNF- $\alpha$ or IL-1 $\beta$ in the spinal cord 
section obtained from mice subject to SCI and treated with GTE.

It also been demonstrated that enhanced formation of NO by iNOS contributes to the inflammatory process. This study demonstrates that GTE attenuates the expression of iNOS in the tissue from SCI treated mice when compared with injured mice.

A novel pathway of inflammation has been proposed in relation to ROS (hydroxyl radical and peroxynitrite) induced strand breaks in DNA, which trigger energyconsuming DNA repair mechanisms and activates the nuclear enzyme PARP resulting in the depletion of its substrate $\mathrm{NAD}^{+}$in vitro and a reduction in the rate of glycolysis. As $\mathrm{NAD}^{+}$functions as a cofactor in glycolysis and the tricarboxylic acid cycle, $\mathrm{NAD}^{+}$depletion leads to a rapid fall in intracellular ATP. This process has been termed 'the PARP Suicide Hypothesis'.

We demonstrate here that the treatment with GTE diminishes the increase in PARP activity in the spinal cord tissue from SCI operated mice. Thus, we proposed that the anti-inflammatory effects of GTE may be at least in part be due to the prevention of the activation of PARP.

Some free radicals, like hydrogen peroxide, causes lipid peroxidation and can lead to cell death (Butterfield and Kanski 2001).

Apoptosis is an important mediator of secondary damage after SCI. Chronologically, apoptosis initially occurs $6 \mathrm{~h}$ post injury at the lesion centre and last for several days associated with a steadily increased number of apoptotic cells in this region. Apoptosis is regulated by expression of BAX, pro-apoptotic protein and Bcl-2,anti-apoptotic protein (Bar-Peled et al. 1999; Nesic-Taylor et al. 2005). Moreover, various studies have postulated that preserving Bax plays an important role in development cell death and in central nervous system injury. In this present study, we showed that SCI is associated with pro-apoptotic transcriptional changes, including up-regulation of Bax expression and down-regulation of Bcl-2 expression. GTE treatment prevented both of these effects.

In conclusion, our results indicate that we are able to produce a substantial reduction of inflammatory events associated with experimental SCI. Our results imply GTE may be useful in the therapy of spinal cord injury, trauma and inflammation.

Acknowledgements The authors would like to thank Carmelo La Spada for their excellent technical assistance during this study, Mrs Caterina Cutrona for secretarial assistance and Miss Valentina Malvagni for editorial assistance with the manuscript.

Open Access This article is distributed under the terms of the Creative Commons Attribution Noncommercial License which permits any noncommercial use, distribution, and reproduction in any medium, provided the original author(s) and source are credited.

\section{References}

Akiyama H, Barger S, Barnum S, Bradt B, Bauer J, Cole GM, Cooper NR, Eikelenboom P, Emmerling M, Finch FBL, CE FS, Griffin WS, Hampel H, Hull M, Landreth G, Lue L, Mrak R, Mackenzie IR, McGeer PL, O'Banion MK, Pachter J, Pasinetti G, PlataSalaman C, Rogers J, Rydel R, Shen Y, Streit W, Strohmeyer R, Tooyoma I, Van Muiswinkel FL, Veerhuis R, Walker D, Webster S, Wegrzyniak B, Wenk G, Wyss-Coray T (2000) Inflammation and Alzheimer's disease. Neurobiol Aging 21(3):383-421

Amar AP, Levy ML (1999) Pathogenesis and pharmacological strategies for mitigating secondary damage in acute spinal cord injury. Neurosurgery 44(5):1027-1039 discussion 1039-1040

Bar-Peled O, Knudson M, Korsmeyer SJ, Rothstein JD (1999) Motor neuron degeneration is attenuated in bax-deficient neurons in vitro. J Neurosci Res 55(5):542-556

Basso DM, Beattie MS, Bresnahan JC (1995) A sensitive and reliable locomotor rating scale for open field testing in rats. J Neurotrauma 12(1):1-21

Beattie MS, Hermann GE, Rogers RC, Bresnahan JC (2002) Cell death in models of spinal cord injury. Prog Brain Res 137:37-47

Beckman JS (1996) Oxidative damage and tyrosine nitration from peroxynitrite. Chem Res Toxicol 9(5):836-844

Butterfield DA, Kanski J (2001) Brain protein oxidation in age-related neurodegenerative disorders that are associated with aggregated proteins. Mech Ageing Dev 122(9):945-962

Carlson GD, Gorden C (2002) Current developments in spinal cord injury research. Spine J 2(2):116-128

Carlson SL, Parrish ME, Springer JE, Doty K, Dossett L (1998) Acute inflammatory response in spinal cord following impact injury. Exp Neurol 151(1):77-88

Chan MM, Fong D, Ho CT, Huang HI (1997) Inhibition of inducible nitric oxide synthase gene expression and enzyme activity by epigallocatechin gallate, a natural product from green tea. Biochem Pharmacol 54(12):1281-1286

Choi YB, Kim YI, Lee KS, Kim BS, Kim DJ (2004) Protective effect of epigallocatechin gallate on brain damage after transient middle cerebral artery occlusion in rats. Brain Res 1019(1-2):47-54

Crespy V, Williamson G (2004) A review of the health effects of green tea catechins in in vivo animal models. J Nutr 134(12 Suppl):3431S$3440 \mathrm{~S}$

Cuzzocrea S, Riley DP, Caputi AP, Salvemini D (2001) Antioxidant therapy: a new pharmacological approach in shock, inflammation, and ischemia/reperfusion injury. Pharmacol Rev 53(1):135-159

de Castro R, Jr HMG, Xu GY, Clifton C, Calingasan NY, Gelman BB, McAdoo DJ (2004) Evidence that infiltrating neutrophils do not release reactive oxygen species in the site of spinal cord injury. Exp Neurol 190(2):414-424

Di Paola R, Mazzon E, Muia C, Genovese T, Menegazzi M, Zaffini R, Suzuki H, Cuzzocrea S (2005) Green tea polyphenol extract attenuates lung injury in experimental model of carrageenaninduced pleurisy in mice. Respir Res 6:66

Dona M, Dell'Aica I, Calabrese F, Benelli R, Morini M, Albini A, Garbisa S (2003) Neutrophil restraint by green tea: inhibition of inflammation, associated angiogenesis, and pulmonary fibrosis. J Immunol 170(8):4335-4341

Endoh M, Maiese K, Wagner J (1994) Expression of the inducible form of nitric oxide synthase by reactive astrocytes after transient global ischemia. Brain Res 651(1-2):92-100

Genovese T, Mazzon E, Di Paola R, Cannavo G, Muia C, Bramanti P, Cuzzocrea S (2005a) Role of endogenous ligands for the peroxisome proliferators activated receptors alpha in the secondary damage in experimental spinal cord trauma. Exp Neurol 194(1):267-278

Genovese T, Mazzon E, Muia C, Bramanti P, De Sarro A, Cuzzocrea $S$ (2005b) Attenuation in the evolution of experimental spinal 
cord trauma by treatment with melatonin. J Pineal Res 38 (3): 198-208

Genovese T, Mazzon E, Muia C, Patel NS, Threadgill MD, Bramanti P, De Sarro A, Thiemermann C, Cuzzocrea S (2005c) Inhibitors of poly(ADP-ribose) polymerase modulate signal transduction pathways and secondary damage in experimental spinal cord trauma. J Pharmacol Exp Ther 312(2):449-457

Genovese T, Mazzon E, Di Paola R, Crisafulli C, Muia C, Bramanti P, Cuzzocrea $S$ (2006a) Increased oxidative-related mechanisms in the spinal cord injury in old rats. Neurosci Lett 393(2-3):141-146

Genovese T, Mazzon E, Menegazzi M, Di Paola R, Muia C, Crisafulli C, Bramanti P, Suzuki H, Cuzzocrea S (2006b) Neuroprotection and enhanced recovery with hypericum perforatum extract after experimental spinal cord injury in mice. Shock 25(6):608-617

Genovese T, Esposito E, Mazzon E, Di Paola R, Meli R, Caminiti R, Bramanti P, Fink MP, Cuzzocrea S (2008) Beneficial effects of ethyl pyruvate in a mouse model of spinal cord injury. Shock

Hirvonen T, Virtamo J, Korhonen P, Albanes D, Pietinen P (2000) Intake of flavonoids, carotenoids, vitamins $\mathrm{C}$ and $\mathrm{E}$, and risk of stroke in male smokers. Stroke 31(10):2301-2306

Joshi M, Fehlings MG (2002) Development and characterization of a novel, graded model of clip compressive spinal cord injury in the mouse: part 2. Quantitative neuroanatomical assessment and analysis of the relationships between axonal tracts, residual tissue, and locomotor recovery. J Neurotrauma 19(2):191-203

Kakuda T (2002) Neuroprotective effects of the green tea components theanine and catechins. Biol Pharm Bull 25(12):1513-1518

Klatsky AL, Armstrong MA, Friedman GD (1993) Coffee, tea, and mortality. Ann Epidemiol 3(4):375-381

La Rosa G, Cardali S, Genovese T, Conti A, Di Paola R, La Torre D, Cacciola F, Cuzzocrea S (2004) Inhibition of the nuclear factorkappaB activation with pyrrolidine dithiocarbamate attenuating inflammation and oxidative stress after experimental spinal cord trauma in rats. J Neurosurg Spine 1(3):311-321

Levites Y, Amit T, Youdim MB, Mandel S (2002) Involvement of protein kinase $\mathrm{C}$ activation and cell survival/ cell cycle genes in green tea polyphenol (-)-epigallocatechin 3-gallate neuroprotective action. J Biol Chem 277(34):30574-30580

Liu SF, Ye X, Malik AB (1997) In vivo inhibition of nuclear factorkappa B activation prevents inducible nitric oxide synthase expression and systemic hypotension in a rat model of septic shock. J Immunol 159(8):3976-3983

Liu D, Ling X, Wen J, Liu J (2000) The role of reactive nitrogen species in secondary spinal cord injury: formation of nitric oxide, peroxynitrite, and nitrated protein. J Neurochem 75(5):2144-2154

Nesic-Taylor O, Cittelly D, Ye Z, Xu GY, Unabia G, Lee JC, Svrakic NM, Liu XH, Youle RJ, Wood TG, McAdoo D, Westlund KN, Hulsebosch CE, Perez-Polo JR (2005) Exogenous Bcl-xL fusion protein spares neurons after spinal cord injury. J Neurosci Res 79 (5):628-637
Ogata K, Mukae N, Suzuki Y, Satoh K, Narumi K, Nukiwa T, Isemura M (1995) Effects of catechins on the mouse tumor cell adhesion to fibronectin. Planta Med 61(5):472-474

Peters RT, Liao SM, Maniatis T (2000) IKKepsilon is part of a novel PMA-inducible IkappaB kinase complex. Mol Cell 5(3):513-522

Salgo MG, Bermudez E, Squadrito GL, Pryor WA (1995) Peroxynitrite causes DNA damage and oxidation of thiols in rat thymocytes [corrected]. Arch Biochem Biophys 322(2):500-505

Sato Y, Nakatsuka H, Watanabe T, Hisamichi S, Shimizu H, Fujisaku S, Ichinowatari Y, Ida Y, Suda S, Kato K et al (1989) Possible contribution of green tea drinking habits to the prevention of stroke. Tohoku J Exp Med 157(4):337-343

Scott GS, Jakeman LB, Stokes BT, Szabo C (1999) Peroxynitrite production and activation of poly (adenosine diphosphate-ribose) synthetase in spinal cord injury. Ann Neurol 45(1):120-124

Scott GS, Cuzzocrea S, Genovese T, Koprowski H, Hooper DC (2005) Uric acid protects against secondary damage after spinal cord injury. Proc Natl Acad Sci U S A 102(9):3483-3488

Serafini M, Ghiselli A, Ferro-Luzzi A (1996) In vivo antioxidant effect of green and black tea in man. Eur J Clin Nutr 50(1):28-32

Stover SL, Fine PR (1987) The epidemiology and economics of spinal cord injury. Paraplegia 25(3):225-228

Sung H, Nah J, Chun S, Park H, Yang SE, Min WK (2000) In vivo antioxidant effect of green tea. Eur J Clin Nutr 54(7):527-529

Szabo C, Lim LH, Cuzzocrea S, Getting SJ, Zingarelli B, Flower RJ, Salzman AL, Perretti M (1997) Inhibition of poly (ADP-ribose) synthetase attenuates neutrophil recruitment and exerts antiinflammatory effects. J Exp Med 186(7):1041-1049

Szabo C, Virag L, Cuzzocrea S, Scott GS, Hake P, O'Connor MP, Zingarelli B, Salzman A, Kun E (1998) Protection against peroxynitrite-induced fibroblast injury and arthritis development by inhibition of poly(ADP-ribose) synthase. Proc Natl Acad Sci U S A 95(7):3867-3872

Tator CH (1995) Update on the pathophysiology and pathology of acute spinal cord injury. Brain Pathol 5(4):407-413

Tator CH, Fehlings MG (1991) Review of the secondary injury theory of acute spinal cord trauma with emphasis on vascular mechanisms. J Neurosurg 75(1):15-26

Tatton WG, Chalmers-Redman RM, Ju WY, Wadia J, Tatton NA (1997) Apoptosis in neurodegenerative disorders: potential for therapy by modifying gene transcription. J Neural Transm Suppl 49:245-268

Townsend PA, Scarabelli TM, Pasini E, Gitti G, Menegazzi M, Suzuki H, Knight RA, Latchman DS, Stephanou A (2004) Epigallocatechin-3-gallate inhibits STAT-1 activation and protects cardiac myocytes from ischemia/reperfusion-induced apoptosis. Faseb J 18(13):1621-1623

Xu J, Kim GM, Chen S, Yan P, Ahmed SH, Ku G, Beckman JS, Xu XM, Hsu CY (2001) iNOS and nitrotyrosine expression after spinal cord injury. J Neurotrauma 18(5):523-532 